\title{
Magnetic Power Loss Characteristics of Non־oriented Electrical Steel Sheets under Stress
}

\author{
Y. Tani, A. Daikoku, M. Nakano, H. Arita, S. Yamaguchi, and Y. Toide \\ Mitsubishi Electric Corporation, 8-1-1 Tsukaguchi-Honmachi, Amagasaki, Hyogo 661-8661, Japan
}

\begin{abstract}
The stress that acts on the core by installing a stator in a frame influences the performance of a motor. To reflect this influence in the equipment design, the stress dependence of the magnetic property was examined for non-oriented electrical steels, which are the core materials. This time, the stress dependence of the magnetic power loss in the range of $\pm 225 \mathrm{MPa}$ was evaluated for high-grade non-oriented electrical steel sheets of $0.5 \mathrm{~mm}$ thickness, and the following results were obtained. (1) The influence on the magnetic power loss is larger under compression than under tensile stress. The loss increases rapidly with an increase in the compressive stress. However, when the stress exceeds -50 MPa, the saturation tendency of the loss gradually becomes strong. (2) The influence of the stress on the magnetic power loss is different in the rolling direction and the traverse direction. (3) A greater magnetic power loss that occurs with compressive stress is mainly due to an increase in hysteresis loss, and the eddy current loss also increases slightly. It is thought that this slight increase in the eddy current loss that occurs with compressive stress depends on the change in the anomalous loss.
\end{abstract}

Key words: non-oriented electrical steel sheets, mechanical stress, magnetic power loss, hysteresis loss, eddy current loss

\section{応力下における無方向性電磁鋼板の鉄損特性 \\ 谷良浩・大穀晃裕・中野正嗣・有田秀哲・山口信一・都出結花利 三菱電機，兵庫県尼崎市塚口本町 8-1-1（率661-8661）}

\section{1. はじめに}

モータの開発では，鉄心素材特性をもとに磁界解析技術を活用 した磁気回路設計を行い，機器性能を事前に算定し，さらなる高 性能化を図る手法が広く行われている。しかし，設計と実機では 性能差が生じるケースが多い. 差異が生じる原因の一つが製造工 程での鉄心加工や組み立てに伴う鉄心磁気特性の劣化であり, 固 定子のフレームへの焼きばめ装着は劣化要因の一つに挙げられる 1). 焼きばめにより固定子コアバックの周方向に圧縮応力が発生す る. その大きさは, 機種, フレーム仕様により千差万別であるが, コアバック部の平均でも数十 $\mathrm{MPa}$, 応力が集中する部位では 150 $\mathrm{MPa}$ 以上となるケースもある2). 応力が影響寸る機器設計に関わる 素材磁気特性として磁化特性と鉄損が挙げられ，前者はモータの コギングトルク性能, 後者は効率性能への影響が懸念される.

そこで筆者らは，印加応力に対する磁気特性の変化をモデル化 した上で，構造解析による応力分布計算と磁界解析の連成により モータ特性を計算する解析システムの開発を行い，コギングトル クへの応力の影響について検討を行った ${ }^{2), 3)}$.この中で, 解析の材 料パラーメータとなる素材磁気特性の弾性变形下での応力依存性 を評価するため, 励磁方向と平行に $100 \mathrm{MPa}$ 超える応力を試料 に均一に付与した状態で計測が可能な磁気特性測定システムを製 作し, 無方向性電磁鋼板の磁化特性への影響を評価した ${ }^{4), 5)}$. 一方, 鉄損については，機器効率化の対策として焼きばめ応力の低減法 が検討されているが6),7)，応力の鉄損一の影響を定量的に把握し設 計に取り入れるまでには至っていない，そこで，この影響をモデ ル化し機器設計に反映すべく，各種無方向性電磁鋼板を対象に応 力下での鉄損についてデータベース化を図っている. 本稿では, $0.5 \mathrm{~mm}$ 厚のハイグレード電磁鋼板を対象に行った $2225 \mathrm{MPa}$ 範 囲での鉄損への影響について報告する.

\section{2. 応力下での鉄損測定法}

\section{1 磁気試験器}

磁気特性の測定には，一枚の平板試料を長手方向に励磁して磁 気特性を評価する単板磁気試験器(SST)を用いた. この SST に励 磁方向と平行に試料を加圧可能な応力印加機構を設け, 応力印加 時の磁気特性を測定できるようにした. 装置の構成を Fig. 1 に示 す. 磁気特性の測定部分はシングルヨーク型の磁路構成で, 試料 を交番励磁した時の磁界の強さ $\mathrm{H}$ と磁束密度 $\mathrm{B}$ を検出コイルによ り測定する. $2 \mathrm{H}$ コイル構成の $\mathrm{H}$ コイルと空隙補償コイル付き $\mathrm{B}$ コイルを, 励磁コイルの中心 $40 \mathrm{~mm}$ の範囲に設置した.

この試験器では, エプスタイン試験器の測定試料を測定対象に 考慮しており, $30 \mathrm{~mm}$ 幅で $180 \mathrm{~mm}$ 300 $\mathrm{mm}$ 長の短冊試料が測 定可能である. 測定では試料の一部 $140 \mathrm{~mm}$ がヨークと接する. ヨーク接触部より両側に延びた試料の一端を固定クランプに拘束 し,もう一方の端部はバネによる応力印加機構(最大印加応力は 0.5 $\mathrm{mm}$ 厚, $30 \mathrm{~mm}$ 幅試料換算で土 $330 \mathrm{MPa}$ )に可動クランプを介し

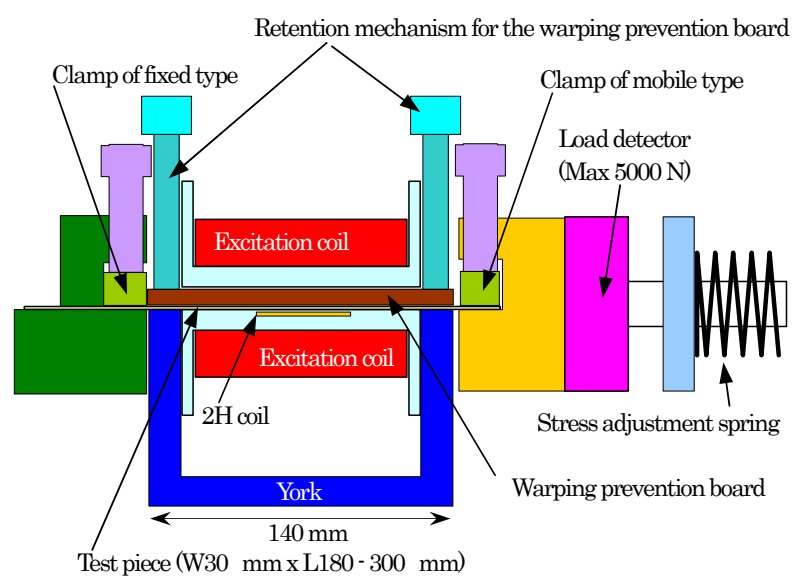

Fig. 1 SST with stress application mechanism. 
Table 1 Specification of test samples.

\begin{tabular}{|c|c|c|}
\hline Sample grade & \multicolumn{2}{|c|}{$50 \mathrm{~A} 290$} \\
\hline $\begin{array}{c}\text { Measurement } \\
\text { direction }\end{array}$ & $\begin{array}{c}\text { Rolling } \\
\text { direction } \\
\text { (RD) }\end{array}$ & $\begin{array}{c}\text { Traverse } \\
\text { direction } \\
\text { (TD) }\end{array}$ \\
\hline $\begin{array}{c}\text { State and shape of } \\
\text { samples }\end{array}$ & \multicolumn{2}{|c|}{$\begin{array}{c}\text { The state cut } \\
\text { with the shearing machine. } \\
\text { T0.5 } \times \text { W30 x L300 mm }\end{array}$} \\
\hline Yield point & \multicolumn{2}{|c|}{$400 \mathrm{MPa}$ or more } \\
\hline Specific resistance $(\mu \Omega \mathrm{m})$ & \multicolumn{2}{|c|}{0.59} \\
\hline
\end{tabular}

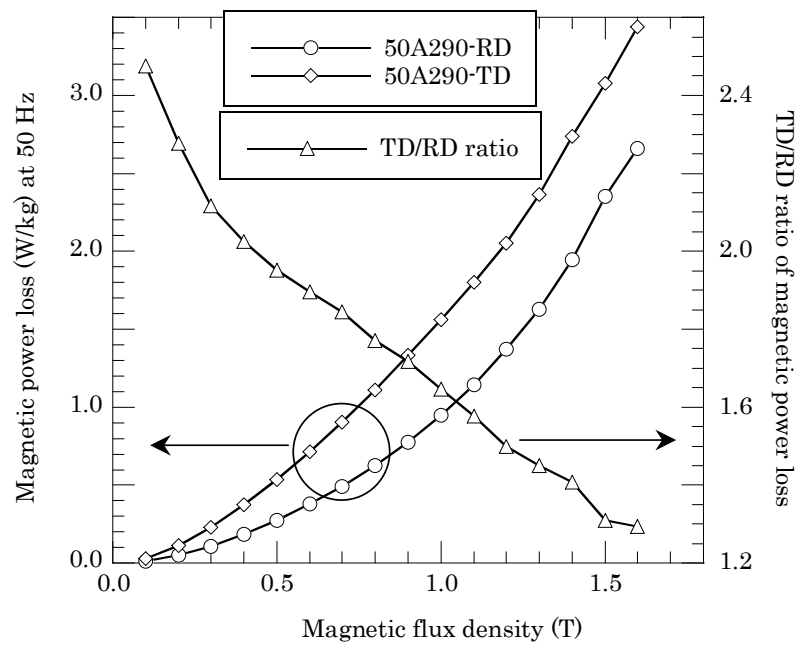

Fig. 2 Magnetic power loss characteristics of test specimens without applied stress at $50 \mathrm{~Hz}$. The difference of the magnetic property of the TD material and the RD material is shown in the TD/RD ratio.

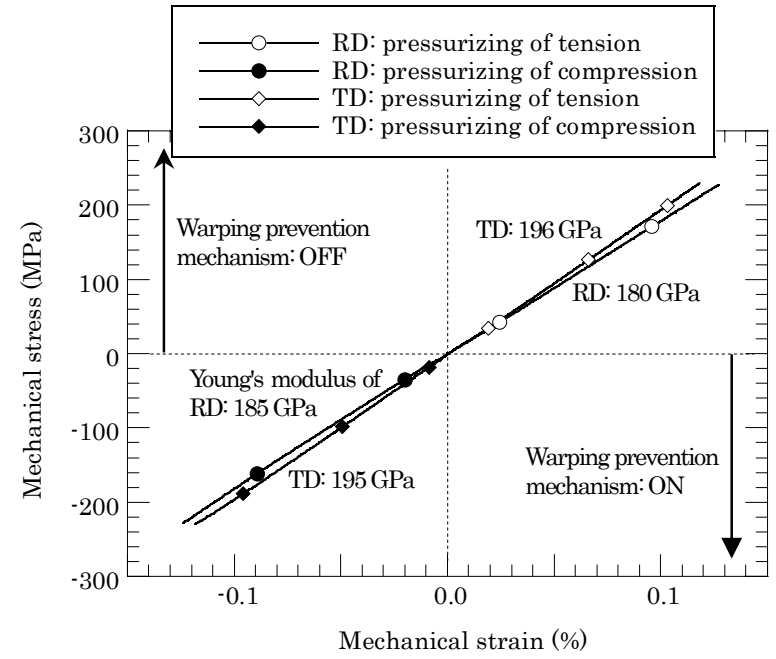

Fig. 3 Mechanical strain characteristics of samples due to applied stress in SST.

て接続している. 拘束・接続のための国み代は片側 $20 \mathrm{~mm}$ で，口 ードセルが可動クランプとバネとの間に配され，加圧力を検出す る. 圧縮時に発生する試料の反り変形を防止するため, ガラスエ ポキシ製バックリング防止板により試料を励磁枠との間にはさみ 平坦性を保持した．なお，防止板の保持はその両端 2 力所を機械 的に拘束した.

鉄損測定は，デジタルフィードバックによる波形制御を行い，
磁束誘起電圧の波形率が $1.11 \pm 1 \%$ となる磁束正弦波条件にて行 った. 以後, この忘力印加機構付き SST を S-SST(SST with stress application mechanism) と呼称する.

\section{2 評価試料と応力印加状態}

今回測定対象とした電磁鋼板はJIS グレード50A290で, Table 1 に示したように, 幅 $30 \mathrm{~mm}$, 長さ $300 \mathrm{~mm}$ サイズの試料長手を 圧延方向(RD), あるいは圧延直交方向(TD)にシャー裁断し測定に 供した. 無方向性電磁鋼板は弱いながらも磁気異方性を有してお り, 異方性の大小はグレードにより異なる. 供試材は $0.5 \mathrm{~mm}$ 板 厚のグレードでは磁気異方性の大きい素材である. 応力無印加で の RD と TD の $50 \mathrm{~Hz}$ 鉄損の差異を Fig. 2 において両供試材の鉄 損と鉄損比率にて示す. そこで, 磁気異方性の存在も考慮し, 鉄 損の応力依存性をエプスタイン試験と同じく圧延方向と圧延直交 方向の二方向にて評価した.

S-SST での応力印加はバネを介した応力制御であり, 測定を弾 性領域で行うために応力印加上限を測定対象試料の降伏点の半分 に設定した. 今回の試料では降伏点が $400 \mathrm{MPa}$ 以上あり, 応力印 加上限を $\pm 225 \mathrm{MPa}$ とした. 試料への応力印加状態を確認するた め, 磁気測定範囲となる試料中央部に金属歪みゲージを接着する と共にバックリング防止板にも歪みゲージ測定用空を設け，応 力・歪み特性を測定した. Fig. 3 に加圧時の測定結果を示す.なお, S-SST のバックリング防止機構は圧縮時のみ使用した. RD, TD 何れの試料もバックリング防止機構を稼働した圧縮下では直線性 が若干乱れるが，応力・歪夕曲線に特に問題となるような大きな 変化は起きていない，また，図中に記した応力・歪夕曲線の傾き より求めたヤング率相当值はメーカ公表值に近い值であること, 引張と圧縮時の值はほぼ同じであることなどの点より, 応力は試 料長手方向の面内に適切に印加されその大きさも試料の弾性範囲 内であると考えられる.

\section{3. 測定結果 · 考察}

\section{1 応力下での交流 B-Hループと鉄損 $(50 \mathrm{~Hz})$}

応力下で $50 \mathrm{~Hz}$ 励磁 した B-H ループの変化を圧延方向材(RD) の最大磁束密度 $B \mathrm{~m}=1.0 \mathrm{~T}$ を例に, 引張応力の場合を Fig. 4 に, 圧縮応力の場合を Fig. 5 にそれぞれ示す.

引張, 圧縮の応力が増加すると, 磁界の強さの最大值と保磁力 は増加し, 逆に残留磁束密度は低下寸る. 特に圧縮時, 磁界の強 さの変化は引張時より一桁程度大きく, 保磁力も応力無印加状態 に比較し 2 倍以上大きくなっている. この保磁力増加の影響によ り磁束密度 $0.3 \mathrm{~T}$ 以下でのループ面積の広がりが際立つなど, 低磁 束密度において圧縮応力の影響が顕著に表れている.

Fig. 6 に圧延方向の磁束密度・鉄損曲線を示寸. 記号の応力無 印加に対し, 引張応力を $200 \mathrm{MPa}$ 加えても鉄損はわずかに増減す るだけであるが，圧縮では-50 MPa の応力でも鉄損は大きく増加 した.

\section{2 鉄損の応力依存性 $(50 \mathrm{~Hz})$}

磁束密度・鉄損曲線のうち $B \mathrm{~m}=0.5,1.0,1.5 \mathrm{~T}$ を代表点に選 び, $50 \mathrm{~Hz}$ での鉄損の応力依存性を Fig. 7 に示寸. さらに, 応力 無印加状態に対寸る鉄損の変化率を Fig. 8, 圧延方向に対する圧延 直交方向の鉄損比の変化を Fig. 9 にそれぞれ示す. 


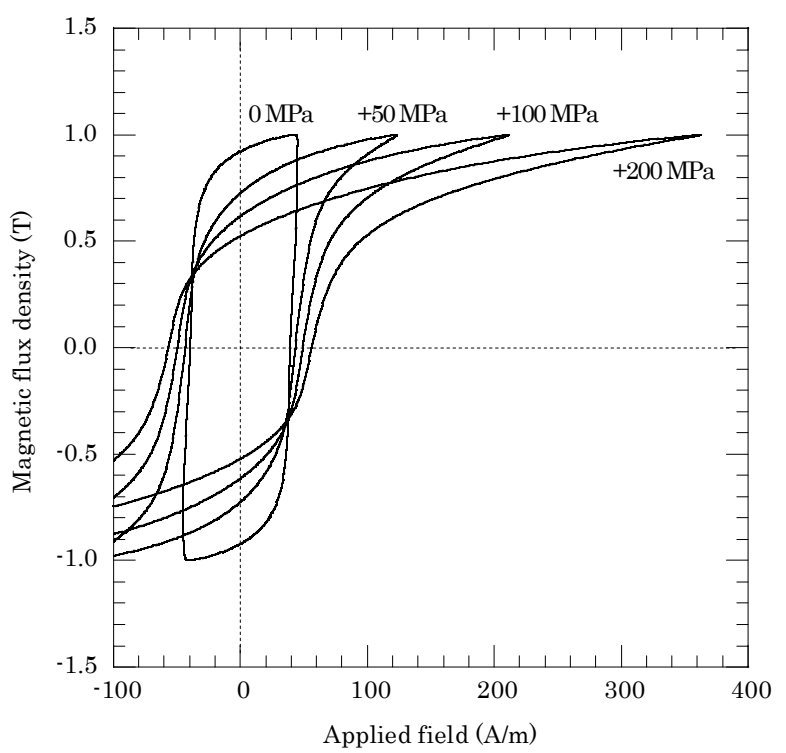

Fig. 4 Comparison of ac B-H curves under tensile stress for 50A290-RD at $50 \mathrm{~Hz}$.

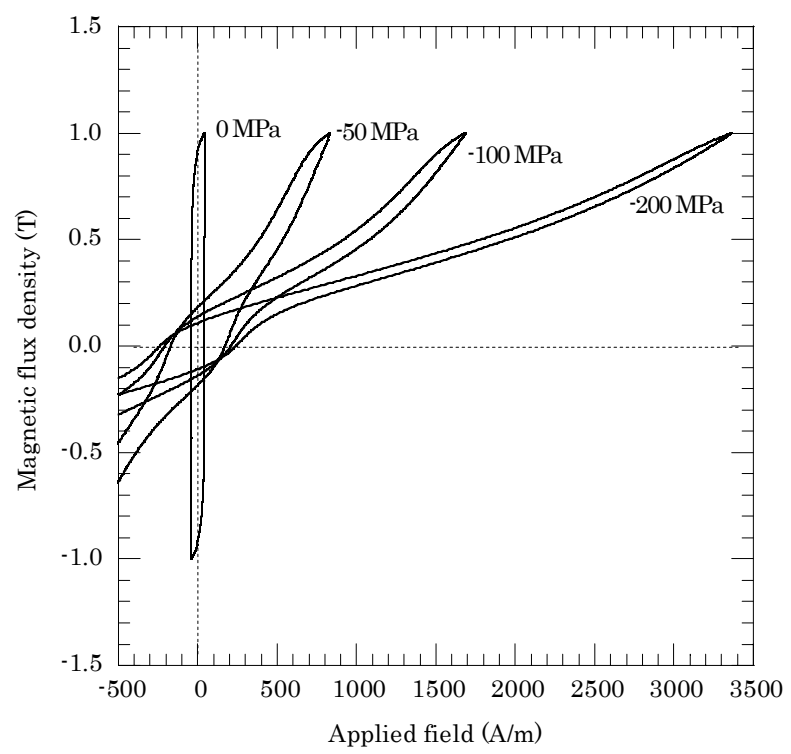

Fig. 5 Comparison of ac B-H curves under compressive stress for 50A290-RD at $50 \mathrm{~Hz}$.

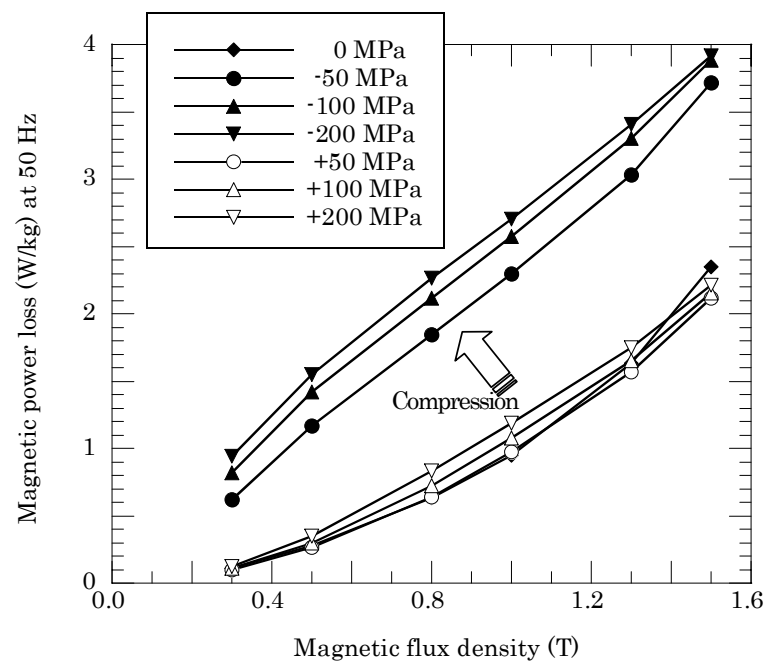

Fig. 6 Change in magnetic power loss due to applied stress for 50A290-RD at $50 \mathrm{~Hz}$.

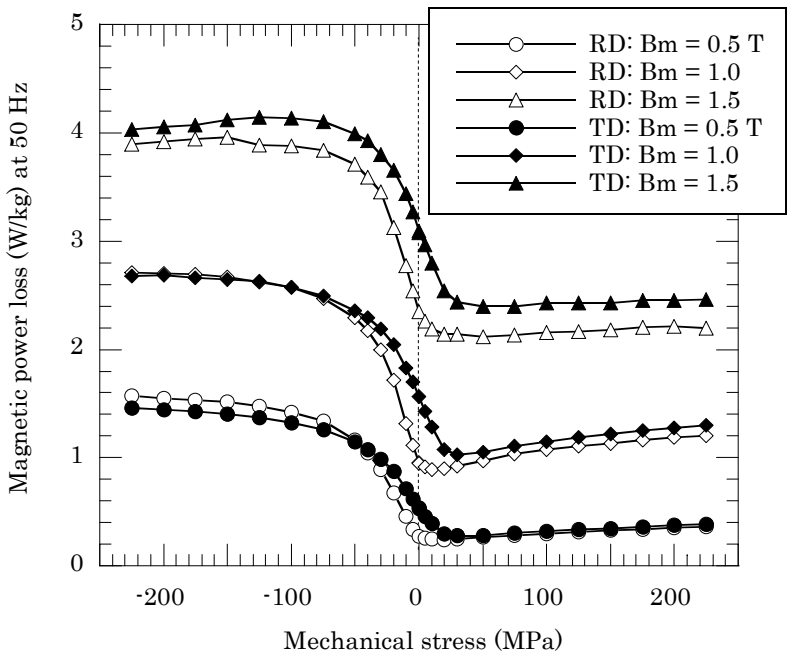

Fig. 7 Stress dependence of the magnetic power loss at $50 \mathrm{~Hz}$.

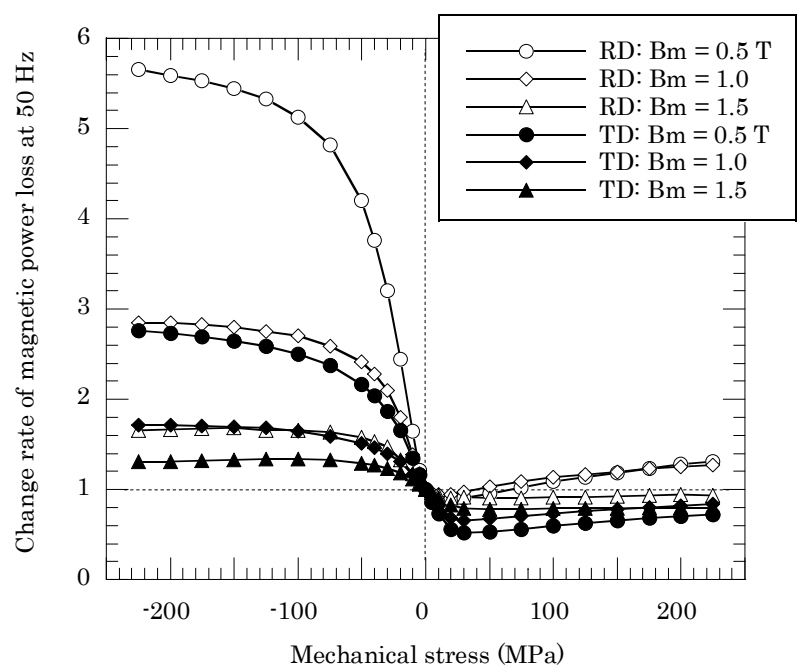

Fig. 8 Change rate of magnetic power loss from the state of no stress due to mechanical stress at $50 \mathrm{~Hz}$.

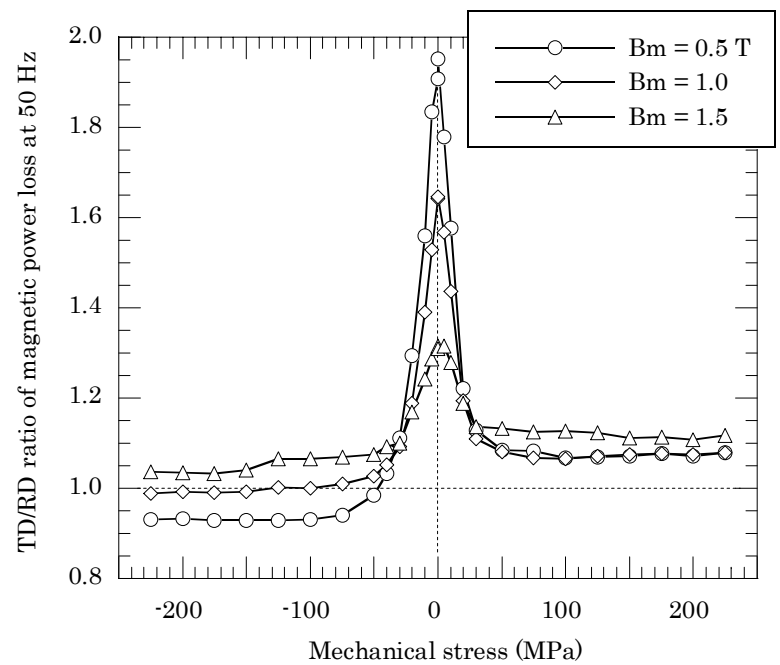

Fig. 9 Change in the TD/RD ratio of the magnetic power loss due to mechanical stress at $50 \mathrm{~Hz}$. 
Fig. 7 から, 引張と圧縮での鉄損は異なる傾向が見られる. 引張 では，応力の増加と共に鉄損は一旦減少した後増加に転じる．圧 延方向の $B \mathrm{~m}=0.5,1.0 \mathrm{~T}$ では，さらに大きな応力を加えると， 無印加時よりも鉄損が増加する. しかし，鉄損の変化は後で述心 る圧縮下での影響に比べ遙かに小さい．圧縮下では小さな応力で も大きな鉄損変化を与え，応力の増加と共に鉄損は増加する．圧 縮応力に対する鉄損の変化は無印加から-50 MPa 付近までは概ね 比例と見なせるが，さらに応力が大きくなると増加は緩やかとな り徐々に飽和傾向を強める.

Fig. 8 より, 応力に対寸る感受性は, 圧縮に対しては圧延方向 (RD), 引張に対しては圧延直交方向(TD)がより敏感である. フレ 一ムが焼きばめされた固定子では，一般にコアバック部周方向に 圧縮心力が分布する．圧縮側だけに着目すれば，RD，TDいずれ の供試材においても-50 MPa 以下の応力では鉄損変化が大きく,

-50 MPa 以上では徐々に飽和傾向を強め, - $100 \mathrm{M} \mathrm{Pa}$ を超える領 域では大きな変化は無い，また，低磁束密度ほど圧縮応力に対す る変化率が大きく，応力に対してより敏感である。

Fig. 9 より, 応力無印加状態では 2 倍近い RD 方向と TD 方向 の鉄損の異方性は応力の印加に伴い低下し，同一值に近づく．異 方性の低下は概ね土50 MPa までの応力印加で起きる. この傾向 は磁束密度が低いほど顕著で，特に圧縮応力下では RD と TD の 大小関係が逆転している.

\section{3 鉄損の構成成分の応力依存性}

鉄損はヒステリシス損 $(W h)$ と渦電流損 $(W \mathrm{e})$ で構成される. 機器 設計はこれらの鉄損成分をもとに磁界解析による鉄損推定が行わ れており, 各成分への応力影響の把握は非常に重要となる. そこ で，鉄損の変化率が大きかった圧縮時の圧延方向について，鉄損 の構成成分への応力影響を調べた. 各鉄損成分は, $B \mathrm{~m}$ と応力が 同じで励磁周波数 $(50,75,100 \mathrm{~Hz})$ が異なる鉄損 $W \mathrm{pl}$ を測定し周 波数分離にて求めた. Fig. 10 に鉄損成分の分離例として $B \mathrm{~m}=1.0$ $\mathrm{T}$ の場合を示寸．なお，Fig. 11 以降の図では，周波数分離で得た Wh, We の係数を基に各鉄損成分を $50 \mathrm{~Hz}$ での損失に換算し示す.

鉄損分離した結果を磁束密度・鉄損成分曲線にてFig. 11 に示寸. 応力無印加でのヒステリシス損は圧縮応力の印加に対し大きな増 加を示すと共に磁束密度 $B$ との依存関係も変化した. そこで, 各 ヒステリシス損の変化を磁束密度の累乗関数として近似し，近似 式と近似曲線(点線)を図中に示寸.一般に応力無印加でのヒステリ シス損は磁束密度の 1.6 乗から 2 乗の值をとるが(今回の測定結果 でも 1.72 乗), 圧縮応力下でのそれは 1 以下となった. 応力の増加 に伴い累乗係数は減少し，ヒステリシス損の磁束密度に対寸る依 存度が高磁束密度側で弱まり, 低磁束密度側で強まる傾向となっ た. 渦電流損も圧縮応力に対し微増してはいるが, Fig. 6 での圧縮 時の鉄損増加の主因はヒステリシス損にあるといえる.

Fig. 7, Fig. 8 に対応するヒステリシス損, 渦電流損の応力依存 性を Fig. 12 に，圧縮応力による変化率を Fig. 13 に示す．ヒステ リシス損, 渦電流損とも $50 \mathrm{MPa}$ 以下では応力印加に比例した損 失の増加を示し，それよりも大きな圧縮心力では飽和していく. また，低磁束密度ほど応力の影響を受けやすい，応力無印加に対 寸る変化率ではヒステリシス損は渦電流損の 2 倍以上大きい.

Fig. 11 での渦電流損が圧縮下で微増した点をより詳細に検討寸
るため, 薄板均一励磁での古典的渦電流損 Wee を(1)式より求め Fig. 12 に示寸.

$$
W_{\text {ce }}=(\pi \cdot t \cdot f \cdot B \mathrm{~m})^{2} /(6 \cdot \rho \cdot \sigma) .
$$

(1)式において, $t$ は試料厚み, $f$ は励磁周波数, $B \mathrm{~m}$ 法磁束密度振 幅， $\rho$ は固有抵抗， $\sigma$ は密度である. 圧縮応力での板厚変動は小 さく古典的渦電流損は応力の影響を受けないとすれば, 圧縮応力 の印加に伴う渦電流損の増加は, 渦電流損と古典的渦電流損の差, 即ち異常渦電流損が圧縮応力の変化に伴い増加したものと考えら れる.

ヒステリシス損の応力に対する変化は, 磁歪を介した磁気弾性 エネルギ一の増減による磁区構造の変化として定性的には説明可 能である1．鉄の磁化容易軸<001>の飽和磁歪は正である。励磁方 向に圧縮応力が作用した場合, 励磁方向に近い<100>では磁気弾 性エネルギーの増加を抑えるよう磁化が向くため, 180 度磁壁が 応力方向と直交する磁区構造の割合が増える. 逆に, 引張応力で

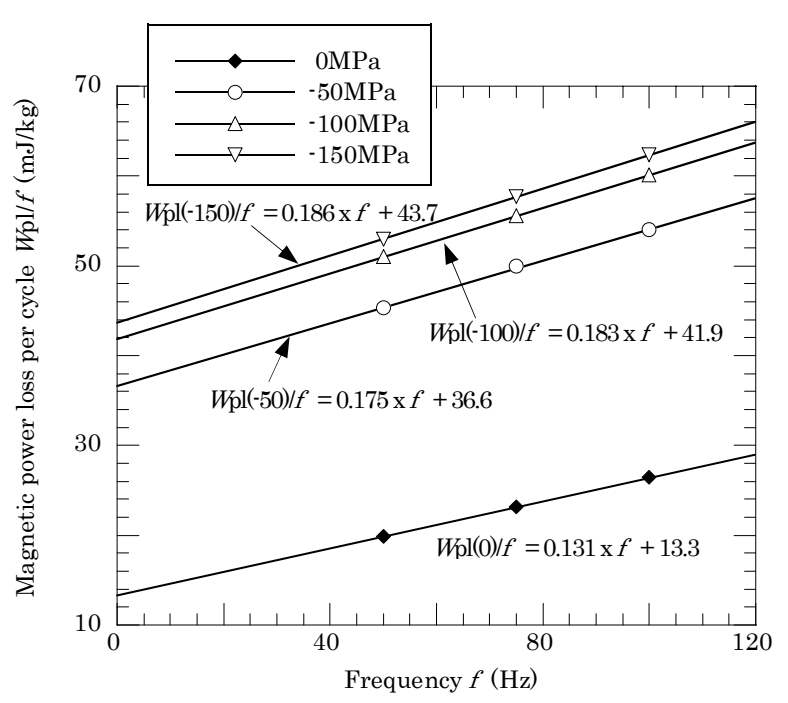

Fig. 10 Frequency dependence of the magnetic power loss in a magnetic flux density of $1 \mathrm{~T}$ for 50A290-RD.

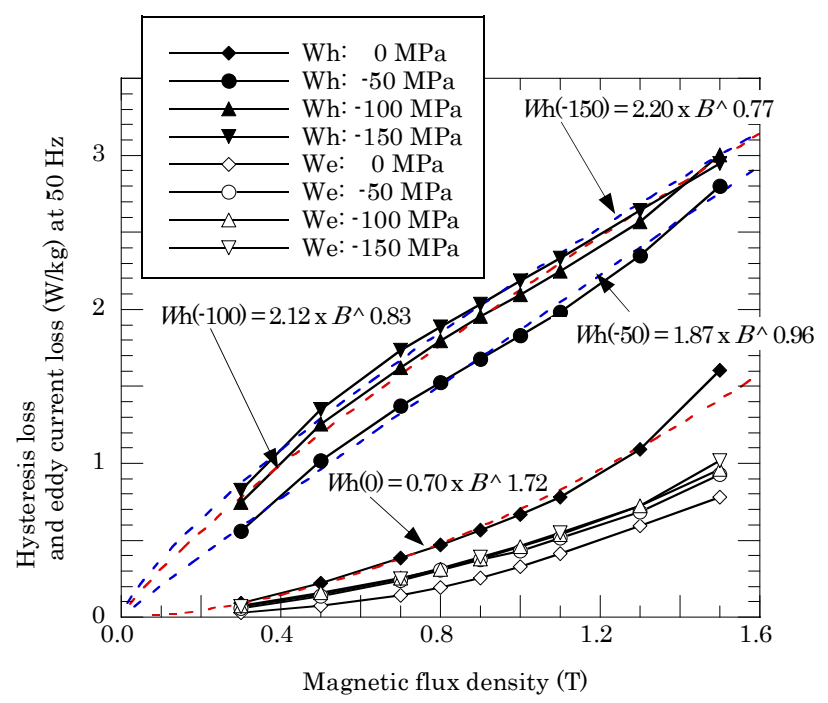

Fig. 11 Change in magnetic power loss elements (that is, hysteresis and eddy current loss) due to compression stress for 50A290-RD at $50 \mathrm{~Hz}$. 
は応力方向に 180 度磁壁が揃う磁区構造の割合が増えると考えら れる. このため, 圧縮時はヒステリシス損の増加等, 磁気特性の 劣化が顕著になる. また, 異常渦電流は磁壁の移動に伴い発生す ることから, 圧縮時の磁区構造の変化が異常渦電流の増加につな がったものと推察される.

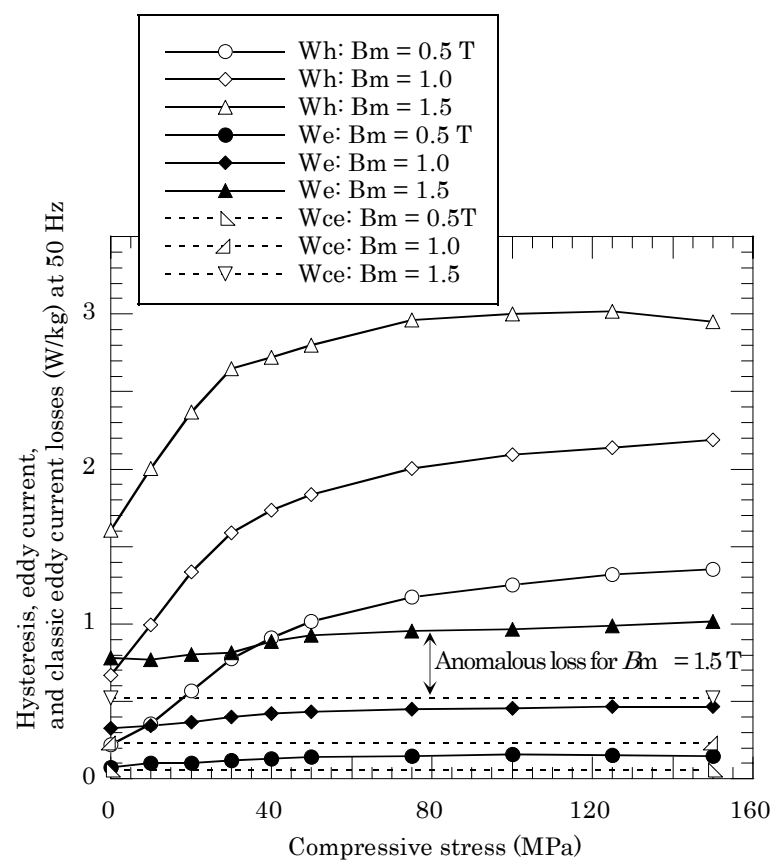

Fig. 12 Stress dependence of the hysteresis, eddy current, and classic eddy current losses for 50A290-RD at $50 \mathrm{~Hz}$.

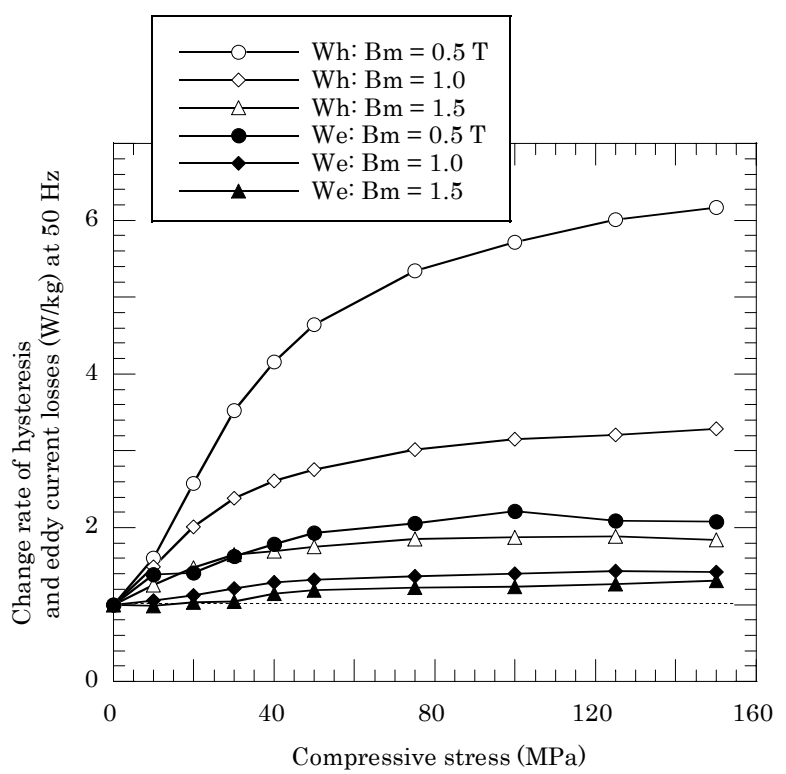

Fig. 13 Change rate of hysteresis and eddy current losses from the state of no stress due to compressive stress for 50A290-RD at $50 \mathrm{~Hz}$.

\section{4. まとめ}

無方向性電磁龬板 50A290 の圧延方向及び圧延直交方向の鉄損 の応力依存性を評価するため, 最大土 $225 \mathrm{MPa}$ までの均一応力を 試料に印加しながら各応力下での鉄損を測定し, 以下の結果を得 た.

（1)直交する 2 方向の試験材を作製したが，いずれの方向でも圧縮 応力では鉄損が急増し, 引張応力では僅かに減少後, 微増に転じ た. 鉄損への影響は压縮時の方が遙かに大きく，低い磁束密度ほ ど顕著である, しかし, 圧縮応力が $50 \mathrm{MPa}$ を超えると徐々に飽 和傾向が強まる.

(2)鋼板の圧延方向と圧延直交方向を比較すると，前者は圧縮応力 に対し敏感なのに対し, 後者は引張応力に対し敏感で, より応力 の影響を受け易い. このため, 応力の印加方向における材料の磁 気異方性は無印加時より低下寸る.

(3)圧縮応力での鉄損劣化の主因はヒステリシス損の増加によるが, 渦電流損の微増も認められた. この渦電流損の微増は異常渦電流 損によるものと考えられる. ヒステリシス損の磁束密度への依存 関係では，圧縮志力の増加と共に高磁束密度での影響度が低下し 低磁束密度での影響度が増した. これら鉄損を構成する成分の圧 縮力に対する変化は, 応力による磁区構造の変化に起因するもの と考えられる.

謝辞 本研究の遂行にあたり S-SST の製作にご尽力いただきまし た東英工業の北邦郎氏を始めとする関係者の皆様に深く感謝いた します.

\section{References}

1) K. Yamamoto, E. Shimomura, K. Yamada, T. Sasaki : T.IEE Japan, 117-A, 311 (1997)(in Japanese).

2) A. Daikoku, M. Nakano, S. Yamaguchi, Y. Tani, Y. Toide, T. Yoshioka, H. Arita, C. Fujino : IEEJ, SA-03-72 / RM-03-74 (2003) (in Japanese).

3) M. Nakano, A. Daikoku, S. Yamaguchi, Y. Tani, H. Arita, Y. Toide, T. Yoshioka, C. Fujino : IEEJ, SA-04-16 / RM-04-16 (2004) (in Japanese).

4) Y. Tani, A. Daikoku, H. Arita, M. Nakano, S. Yamaguchi, Y. Toide, T. Yoshioka, C. Fujino : IEEJ, MAG-03-191 (2003) (in Japanese).

5) Y. Tani, A. Daikoku, M. Nakano, H. Arita, Y. Toide, T. Yoshioka, S. Yamaguchi, C. Fujino : IEEJ, MAG-04-91 (2004) (in Japanese).

6) H. Hiwaki, Y. Yoshikawa, T. Funatsu, T. Tamamura, H. Murakami, Y. Honda : IEEJ, RM-04-63 (2004) (in Japanese).

7) M. Satoh, S. Kaneko, M. Tomita, S. Doki, S. Okuma : JIASC2005, 3-91 (2005) (in Japanese).

\section{5年10月19日受理，2005年12月16日採録}

